\title{
Correlation of plasma crizotinib trough concentration with adverse events in patients with anaplastic lymphoma kinase positive non-small-cell lung cancer
}

Yasuko Kurata ${ }^{1 \dagger}$, Narumi Miyauchi $^{2+}{ }^{+}$, Manabu Suno ${ }^{2 *}$, Takahiro Ito $^{2}$, Toshiaki Sendo ${ }^{1}$ and Katsuyuki Kiura ${ }^{3}$

\begin{abstract}
Background: Crizotinib, an ATP-competitive receptor tyrosine kinase inhibitor of both anaplastic lymphoma kinase (ALK) and the hepatocyte growth factor receptor, commonly causes several adverse events (AEs). The clinical utility of measuring the plasma concentration of crizotinib in patients with non-small-cell lung cancer (NSCLC) has not been fully elucidated. The aim of this study was to evaluate the variability in the crizotinib trough concentration and its relationship with the occurrence of AEs in NSCLC patients.
\end{abstract}

Findings: Plasma samples were collected from 9 ALK fusion gene-positive NSCLC Japanese patients at day 14 after the first administration of crizotinib. We assessed crizotinib-induced AEs on days 7, 14, 21, and 28. The crizotinib trough concentration on day 14 ranged from 243.5 to $847.8 \mathrm{ng} / \mathrm{mL}$, and all of the patients achieved stable disease based on assessment of the tumor response on day 28. The cumulative number of AEs on day 28 in the higher trough concentration group was approximately 3 -fold greater than that in the lower trough concentration group. AEs of grade 3 or 4 were observed only in patients in the higher trough concentration group.

Conclusions: The occurrence of several AEs may correlate with the increase in the crizotinib trough concentration. Monitoring of the crizotinib trough concentration could predict the risk of development of several AEs and provide guidance for determining the optimal dose of crizotinib.

Keywords: Crizotinib, Therapeutic drug monitoring, Adverse events, LC-MS/MS

\section{Findings}

\section{Background}

Several tyrosine kinase inhibitors, including gefitinib, erlotinib, and crizotinib, have demonstrated substantial single-agent activity in the treatment of metastatic nonsmall-cell lung cancer (NSCLC) [1-3]. Among these drugs, crizotinib is an ATP-competitive receptor tyrosine kinase inhibitor of both anaplastic lymphoma kinase (ALK) and hepatocyte growth factor receptor (c-MET) tyrosine kinases. Crizotinib blocks intracellular signaling pathways and reduces the growth and size of tumors [4-8]. The

\footnotetext{
*Correspondence: sunoma@pharm.okayama-u.ac.jp

${ }^{\dagger}$ Equal contributors

${ }^{2}$ Department of Oncology Pharmaceutical Care \& Sciences, Graduate School of Medicine, Dentistry and Pharmaceutical Sciences, Okayama University, Okayama 700-8530, Japan

Full list of author information is available at the end of the article
}

recommended oral dose of crizotinib is $250 \mathrm{mg}$ twice daily, and a steady-state can be reached within 2 weeks $[8,9]$. A clinical trial of crizotinib has reported that the maximum drug concentration $(\mathrm{Cmax})$ and area under the concentration-time curve (AUC) of crizotinib in Asian patients were higher than that in non-Asian patients [10]. Although the difference in physical size might influence the plasma concentration of crizotinib, patients undergo treatment with a fixed dose level of crizotinib. Crizotinib causes severe adverse events (AEs), such as leucopenia, neutropenia, elevated alanine aminotransferase (ALT) levels, and QT interval prolongation [10-16]. However, the relationship between the plasma concentration of crizotinib and AEs has not yet been determined in patients. Therefore, measuring crizotinib concentrations in the plasma of patients may be substantially beneficial for 
predicting AEs and for defining the optimal dose of crizotinib.

In the present study, we quantitated crizotinib in the plasma of patients using a liquid chromatography-tandem mass spectrometry (LC-MS/MS) method and also investigated the relationship between crizotinib trough concentration and crizotinib-induced AEs based on clinical data.

\section{Methods}

\section{Ethics}

This study was designed and implemented following the guidelines dictated in the Declaration of Helsinki. Ethics approval was obtained from the Okayama University Graduate School of Medicine, Dentistry, and Pharmaceutical Sciences Ethics Committee. Patients in this study remained anonymous. Written informed consent was obtained from patients in the prospective study. All patients received medical care and treatment according to the protocols and policies of the hospital without being influenced by this study.

\section{Patients and plasma samples}

Plasma samples were collected from 9 ALK fusion genepositive NSCLC Japanese patients receiving a daily oral dose of either 400 or $500 \mathrm{mg}$ of crizotinib between August 2012 and July 2013 at Okayama University Hospital. Since crizotinib reaches a steady-state within 2 weeks, we collected plasma samples before the patients had taken crizotinib in the morning at day 14 after the first dose of crizotinib. Venous blood $(1.0 \mathrm{~mL})$ was collected in heparinized tubes. The supernatant in the centrifuged tubes were collected and stored at $-30^{\circ} \mathrm{C}$ until analysis.

Patient information, including age, sex, height, weight, performance status (PS), disease stage (based on the TNM classification), and previous chemotherapy for NSCLC were obtained from their medical records. The incidence of AEs was assessed on treatment days 7, 14, 21, and 28. The grades of AEs were assessed using the grading system of Common Terminology Criteria for Adverse Events (version 4.0) [17]. To assess the correlation on the number of AEs with crizotinib trough concentration, the trough concentrations were divided into a higher trough concentration group $(\mathrm{n}=5)$ and a lower trough concentration group $(\mathrm{n}=4)$ delimited at the median concentration $(508.5 \mathrm{ng} / \mathrm{mL})$.

Correlations of crizotinib trough concentration with patient data [height, weight, body mass index (BMI), and body surface area (BSA)] were all determined using the Pearson's correlation coefficient. The differences in the number of AEs between the patients in the higher and in the lower trough concentration groups were evaluated by the Mann-Whitney $U$ test. A $p$ value less than 0.05 was considered significant.

\section{Determination of crizotinib in the plasma of patients}

Crizotinib was measured in the plasma samples using a LCMS/MS method that we developed. One hundred $\mu \mathrm{L}$ of plasma was mixed with an internal standard (IS; erlotinib) solution, and then $200 \mu \mathrm{L}$ of methanol was added for the deproteinization step. The mobile phase was composed of $0.1 \%$ formic acid in a water and acetonitrile mixture (70:30, $\mathrm{v} / \mathrm{v})$. The ion transitions for crizotinib and the IS were 451.1/ 261.0 and 394.1/177.0, respectively. The detection was linear in human plasma at concentrations ranging from 10 to $1000 \mathrm{ng} / \mathrm{mL}$ for crizotinib $(\mathrm{y}=0.0009 \mathrm{x}-0.0021 ; r=0.999$, $p<0.001)$. The assay accuracy at $5,10,100,200,500$, and $1000 \mathrm{ng} / \mathrm{mL}$ ranged from 95.6 to $104.1 \%$ (intra-assay) and from 95.9 to $104.1 \%$ (inter-assay), respectively. The assay precision at 5 different concentrations ranged from 1.5 to $4.5 \%$ (intra-assay) and from 3.2 to $4.4 \%$ (inter-assay), respectively.

\section{Results}

\section{Patient demographic characteristics}

Table 1 shows the characteristics of the 9 patients. Patients had been diagnosed with either postoperative recurrence

Table 1 Patient characteristics

\begin{tabular}{|c|c|c|c|c|c|c|c|c|c|}
\hline Patient & Age & Sex & $\begin{array}{l}\text { Height } \\
(\mathrm{cm})\end{array}$ & $\begin{array}{l}\text { Weight } \\
\text { (kg) }\end{array}$ & $\begin{array}{l}\text { BMI } \\
\left(\mathrm{kg} / \mathrm{m}^{2}\right)\end{array}$ & $\begin{array}{l}\text { BSA } \\
\left(\mathrm{m}^{2}\right)\end{array}$ & PS & $\begin{array}{l}\text { Disease } \\
\text { stage }\end{array}$ & Previous chemotherapy \\
\hline 1 & 41 & $\mathrm{~F}$ & 154.2 & 43.6 & 18.3 & 1.38 & 1 & IV & CDDP + DTX, VNR + GEM, PEM \\
\hline 2 & 40 & $M$ & 173.5 & 61.2 & 20.3 & 1.73 & 1 & IV & No previous chemotherapy. \\
\hline 3 & 62 & $M$ & 175.5 & 81.3 & 26.4 & 1.97 & 0 & $\| \mathrm{A}$ & CBDCA + PTX, CDDP + DTX, Bevacizumab, CPT-11 + AMR + Bevacizumab \\
\hline 4 & 75 & $\mathrm{~F}$ & 146.4 & 36.8 & 17.2 & 1.24 & 1 & $\| \mathrm{A}$ & CBDCA + PEM \\
\hline 5 & 52 & $\mathrm{~F}$ & 158.0 & 64.2 & 25.7 & 1.65 & 1 & IV & CDDP + PEM, PEM \\
\hline 6 & 57 & $\mathrm{~F}$ & 147.5 & 47.9 & 22.0 & 1.39 & 1 & $\| \mathrm{A}$ & CBDCA + PTX, CDDP + VNR \\
\hline 7 & 57 & $\mathrm{~F}$ & 155.2 & 35.1 & 14.6 & 1.26 & 1 & $\| A$ & CBDCA + PTX \\
\hline 8 & 67 & $\mathrm{~F}$ & 146.5 & 42.4 & 19.8 & 1.31 & 1 & IV & No previous chemotherapy \\
\hline 9 & 54 & $\mathrm{~F}$ & 157.8 & 58.9 & 23.7 & 1.59 & 1 & IV & CDDP + PEM, PEM \\
\hline
\end{tabular}


Table 2 Quantification of crizotinib in the plasma of patients, adjusted doses, and adverse events

\begin{tabular}{|c|c|c|c|c|}
\hline Patient & $\begin{array}{l}\text { Daily dose of } \\
\text { crizotinib }^{\mathrm{a}} \\
\text { (mg/day) }\end{array}$ & $\begin{array}{l}\text { Trough concentration } \\
(\mathrm{ng} / \mathrm{mL}(\mu \mathrm{M}))\end{array}$ & $\begin{array}{l}\text { Tumor response } \\
\text { on day } 28\end{array}$ & Crizotinib-induced adverse events $^{b}$ \\
\hline 1 & $400^{a}$ & $589.3(1.31)$ & SD & Fatigue, staggering, dysgeusia, neutropenia***, AST elevation \\
\hline 2 & 500 & $314.1(0.70)$ & SD & Nausea, neutropenia \\
\hline 3 & 500 & $370.8(0.82)$ & SD & Fatigue, AST and ALT elevations \\
\hline 4 & 500 & $825.2(1.83)$ & SD & $\begin{array}{l}\text { Fatigue, staggering, eye disorder, dysgeusia, nausea, anorexia, AST elevation, } \\
\text { constipation }\end{array}$ \\
\hline 5 & 500 & $847.8(1.88)$ & SD & $\begin{array}{l}\text { Fatigue, eye disorder, dysgeusia, nausea, vomiting, constipation, diarrhea, rise } \\
\text { in creatinine levels, leukopenia***, neutropenia***, AST and ALT elevations }\end{array}$ \\
\hline 6 & 500 & $470.8(1.05)$ & SD & $\begin{array}{l}\text { Fatigue, eye disorder, dysgeusia, constipation, diarrhea, neutropenia, AST } \\
\text { elevation }\end{array}$ \\
\hline 7 & 500 & $573.6(1.27)$ & SD & $\begin{array}{l}\text { Staggering, anorexia, dysgeusia, nausea, constipation, neutropenia, vomiting, } \\
\text { AST elevation, QT interval prolongation*** }\end{array}$ \\
\hline 8 & 500 & $508.5(1.13)$ & SD & Nausea, vomiting, anorexia, neutropenia, AST and ALT elevations*** \\
\hline 9 & 500 & $243.5(0.54)$ & SD & Eye disorder \\
\hline
\end{tabular}

AST; aspartate aminotransferase, ALT; alanine aminotransferase, SD; stable disease.

aPlasma collection was conducted after the dosage had been adjusted due to crizotinib-induced adverse events. The plasma of patients was collected at day 14 before crizotinib was taken in the morning and was analyzed as the trough sample.

${ }^{\mathrm{b}}$ All adverse events developed in each patient at days 7, 14, 21 and 28 were listed.

$*^{* *}$ is grade $3,^{* * * *}$ is grade 4 , and other adverse events were grade 1 or 2 .

or metastatic NSCLC which were all adenocarcinoma, and all patients had ALK fusion gene-positive NSCLC without epidermal growth factor receptor mutations. Patients \#2 and \#5 had no past surgical history, and patients \#2 and \#8 had no previous history of chemotherapy before receiving crizotinib.

The crizotinib trough concentration and adverse events Nine analytes collected on day 14 were treated as the crizotinib trough concentrations. The median crizotinib trough concentration was $508.5 \mathrm{ng} / \mathrm{mL}$ with a range from 243.5 to $847.8 \mathrm{ng} / \mathrm{mL}$. Tumor responses in all of the patients on day 28 were considered as stable disease independent to the crizotinib trough concentration. The AEs observed in the patients on day 7, 14, 21, and 28 are shown in Table 2. The most frequent AEs were neutropenia and AST elevation (Figure 1). The cumulative number of AEs on day 28 in the higher trough concentration group was approximately 3-fold greater than that in the lower trough concentration group (Figure 2). AEs of grade 3 or 4 were

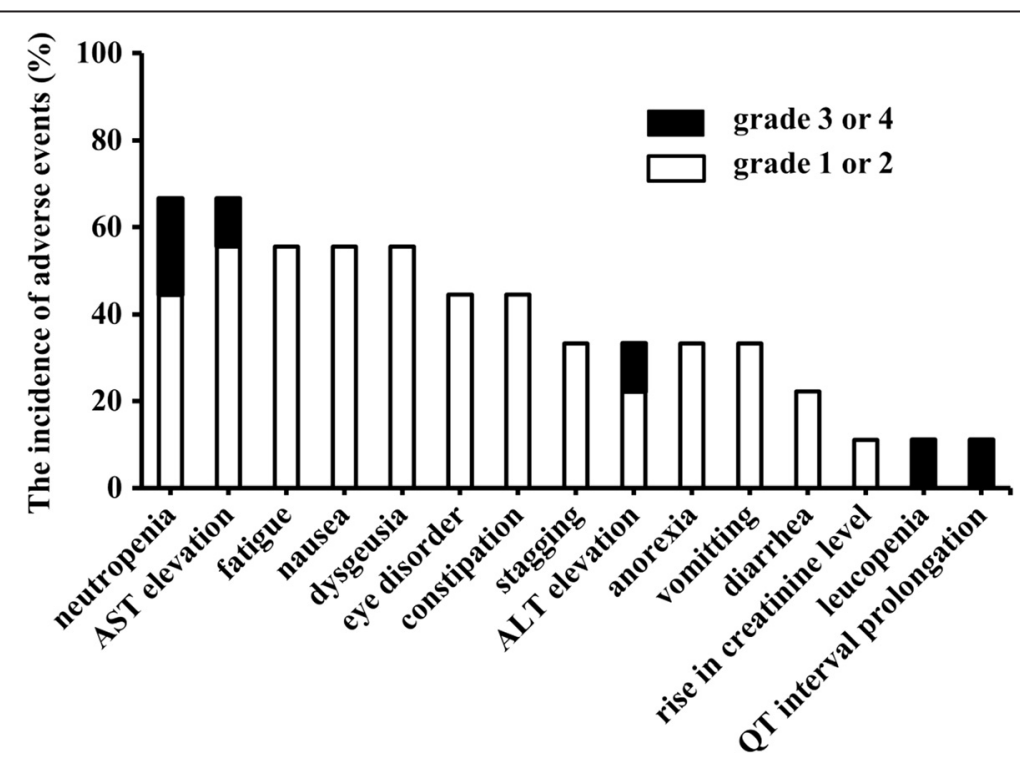

Figure 1 The incidence of adverse events in patients. The incidence of AEs was assessed on treatment days 7, 14, 21, and 28. The grades of AEs were assessed using the grading system of Common Terminology Criteria for Adverse Events (version 4.0). 


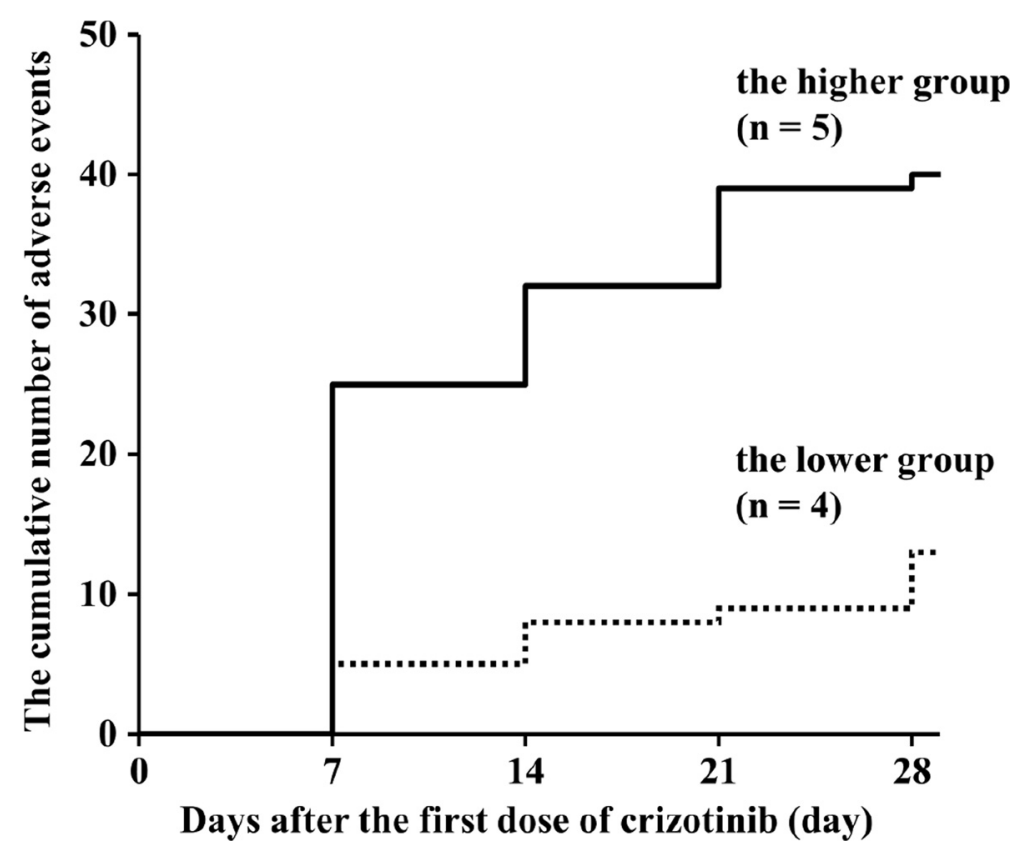

Figure 2 The cumulative numbers of adverse events in the higher and in the lower crizotinib trough concentration groups. The crizotinib trough concentration is divided into a higher trough concentration group ( $n=5,-$ ) and a lower trough concentration group $(\mathrm{n}=4,-\ldots \ldots-$ - $)$ delimited at the median concentration $(508.5 \mathrm{ng} / \mathrm{mL})$. Adverse events were evaluated four times (day $7,14,21$, and 28$)$.

observed only in the patients in the higher trough concentration group. However, a significant difference in the number of AEs between the higher and the lower trough concentration groups was not observed.

\section{Discussion}

Although all of the patients presented with variable crizotinib trough concentrations on day 14, they achieved stable disease according to the assessment of tumor response on day 28. In addition, there was a difference in the frequency of AEs on day 28 between the higher and the lower crizotinib trough concentration groups.

Crizotinib shows promising results in the treatment of ALK fusion gene-positive NSCLC with a recommended dose of $500 \mathrm{mg} /$ day [18]. However, sensitivity to crizotinib may differ among individuals due to many determinants, and may result in developing several different AEs. Based on data from a previous clinical trial of crizotinib, the median trough concentration of crizotinib at a steady-state ranged from 242 to $319 \mathrm{ng} / \mathrm{mL}$ [19]. Therefore, some patients in our study might have maintained an elevated crizotinib trough concentration. One crizotinib clinical trial has reported that the Cmax and AUC of crizotinib in Asian patients were 1.57 - and 1.50 -fold that in non-Asian patients, respectively, and body weight and BSA are thought to be important factors for the pharmacokinetic parameters of crizotinib $[10,16,19]$. In our study, height, weight, BMI, and BSA with the patients in the higher trough concentration group were likely to be smaller than that with the patients in the lower trough concentration group, however, a significant difference was not observed. Patients in the higher trough concentration group were likely to experience a greater cumulative number of AEs, some of which were grade 3 or 4 . These AEs included neutropenia, leucopenia, AST and ALT elevation, and QT interval prolongation. On the other hand, patients in the lower trough concentration group experienced AEs of only grade 1 or 2 during the monitoring period and were more able to tolerate the crizotinib treatment. Therefore, the occurrence and worsening of AEs could be related to the increase in the crizotinib trough concentration. A dose of crizotinib adjusted to the individual patients might be needed for efficient treatment. A limitation of our study was the paucity of patients which was related to the ALK gene rearrangement is observed in $3-7 \%$ of NSCLC [3]. Multicenter study would be needed to demonstrate the relationship between the plasma concentration of crizotinib and AEs.

In conclusion, an increasing crizotinib trough concentration might lead to multiple AEs of various grades. The monitoring of crizotinib trough concentration could predict the risk of development of AEs and be a guide for determining the optimal dose of crizotinib.

\section{Abbreviations}

AEs: Adverse events; ALK: Anaplastic lymphoma kinase; ALT: Alanine aminotransferase; AST: Aspartate aminotransferase; AUC: Area under the concentration-time curve; BMI: Body mass index; BSA: Body surface area; Cmax: Maximum drug concentration; C-MET: Hepatocyte growth factor receptor; IS: Internal standard; LC-MS/MS: Liquid chromatography with 
tandem mass spectrometry; NSCLC: Non-small-cell lung cancer;

PS: Performance status; TNM: Tumor, lymph nodes and metastasis.

\section{Competing interests}

The authors declare that they have no competing interests.

\section{Authors' contributions}

YK participated in the data acquisition in the clinical examination. NM carried out the LC-MS/MS analysis and helped to draft the manuscript. MS carried out the management of the clinical data and drafted the manuscript. TI participated in the data acquisition in the clinical examination. TS conceived of the study, participated in its design and coordination, and helped to draft the manuscript. KK participated in both the study design and coordination and helped to draft the manuscript. All authors have read and approved the final manuscript.

\section{Author details}

'Department of Pharmacy, Okayama University Hospital, Okayama 700-8558, Japan. ${ }^{2}$ Department of Oncology Pharmaceutical Care \& Sciences, Graduate School of Medicine, Dentistry and Pharmaceutical Sciences, Okayama University, Okayama 700-8530, Japan. ${ }^{3}$ Department of Allergy and Respiratory, Okayama University Hospital, Okayama 700-8558, Japan.

Received: 14 July 2014 Accepted: 14 November 2014

Published online: 02 March 2015

\section{References}

1. Shames DS, Wistuba II: The evolving genomic classification of lung cancer. J Pathol 2014, 232(2):121-133.

2. Pao W, Girard N: New driver mutations in non-small-cell lung cancer. Lancet Oncol 2011, 12(2):175-180.

3. Ulivi P, Zoli W, Capelli L, Chiadini E, Calistri D, Amadori D: Target therapy in NSCLC patients: relevant clinical agents and tumor molecular characterization. Mol Clin Oncol 2013, 1(4):575-581.

4. Cui JJ, Tran-Dubé M, Shen H, Nambu M, Kung PP, Pairish M, Jia L, Meng J, Funk L, Botrous I, McTigue M, Grodsky N, Ryan K, Padrique E, Alton G, Timofeevski S, Yamazaki S, Li Q, Zou H, Christensen J, Mroczkowski B, Bender S, Kania RS, Edwards MP: Structure based drug design of crizotinib (PF-02341066), a potent and selective dual inhibitor of mesenchymalepithelial transition factor (c-MET) kinase and anaplastic lymphoma kinase (ALK). J Med Chem 2011, 54(18):6342-6363.

5. Soda M, Choi YL, Enomoto M, Takada S, Yamashita Y, Ishikawa S, Fujiwara S, Watanabe H, Kurashina K, Hatanaka H, Bando M, Ohno S, Ishikawa Y, Aburatani H, Niki T, Sohara Y, Sugiyama Y, Mano H: Identification of the transforming EML4-ALK fusion gene in non-small-cell lung cancer. Nature 2007, 448(7153):561-566.

6. Koivunen JP, Mermel C, Zejnullahu K, Murphy C, Lifshits E, Holmes AJ, Choi HG, Kim J, Chiang D, Thomas R, Lee J, Richards WG, Sugarbaker DJ, Ducko C, Lindeman N, Marcoux JP, Engelman JA, Gray NS, Lee C, Meyerson M, Jänne PA: EML4-ALK fusion gene and efficacy of an ALK kinase inhibitor in lung cancer. Clin Cancer Res 2008, 14(13):4275-4283.

7. Gandhi L, Jänne PA: Crizotinib for ALK-rearranged non-small cell lung cancer: a new targeted therapy for a new target. Clin Cancer Res 2012, 18(14):3737-3742

8. Timm A, Kolesar JM: Crizotinib for the treatment of non-small-cell lung cancer. Am J Health Syst Pharm 2013, 70(11):943-957.

9. Kwak EL, Camidge DR, Clark J, Shapiro Gl, Maki RG, Ratain MJ, Solomon B, Bang Y, Ou S, Salgia R: Clinical activity observed in a phase I dose escalation trial of an oral c-met and ALK inhibitor, PF-02341066 [abstract]. J Clin Oncol 2009, 27(15S):suppl. 3509.

10. Center for Drug Evaluation and Research, Application Number: 2025700rig1s000, MEDICAL REVIEW(S). [http://www.accessdata.fda.gov/ drugsatfda_docs/nda/2011/2025700rig1s000MedR.pdf]

11. Kwak EL, Bang YJ, Camidge DR, Shaw AT, Solomon B, Maki RG, Ou SH, Dezube BJ, Jänne PA, Costa DB, Varella-Garcia M, Kim WH, Lynch TJ, Fidias P, Stubbs H, Engelman JA, Sequist LV, Tan W, Gandhi L, Mino-Kenudson M, Wei GC, Shreeve SM, Ratain MJ, Settleman J, Christensen JG, Haber DA, Wilner K, Salgia R, Shapiro Gl, Clark JW, et al: Anaplastic lymphoma kinase inhibition in non-small-cell lung cancer. N Engl J Med 2010, 363(18):1693-1703.
12. Crinò L, Kim D, Riely GJ, Janne PA, Blackhall FH, Camidge DR, Hirsh V, Mok T, Solomon BJ, Park K, Gadgeel SM, Martins R, Han J, De Pas TM, Bottomley A, Polli A, Petersen J, Tassell VR, Shaw AT: Initial phase II results with crizotinib in advanced ALK-positive non-small cell lung cancer (NSCLC): PROFILE 1005 [abstract]. J Clin Oncol 2011, 29(15):suppl. 7514.

13. Shaw AT, Kim DW, Nakagawa K, Seto T, Crinó L, Ahn MJ, De Pas T, Besse B, Solomon BJ, Blackhall F, Wu YL, Thomas M, O'Byrne KJ, Moro-Sibilot D, Camidge DR, Mok T, Hirsh V, Riely GJ, lyer S, Tassell V, Polli A, Wilner KD, Jänne PA: Crizotinib versus chemotherapy in advanced ALK-positive lung cancer. N Engl J Med 2013, 368(25):2385-2394.

14. Scagliotti G, Stahel RA, Rosell R, Thatcher N, Soria JC: ALK translocation and crizotinib in non-small cell lung cancer: an evolving paradigm in oncology drug development. Eur J Cancer 2012, 48(7):961-973.

15. Ou SH: Crizotinib: a novel and first-in-class multitargeted tyrosine kinase inhibitor for the treatment of anaplastic lymphoma kinase rearranged non-small cell lung cancer and beyond. Drug Des Devel Ther 2011, 5:471-485.

16. Camidge DR, Bang YJ, Kwak EL, lafrate AJ, Varella-Garcia M, Fox SB, Riely GJ, Solomon B, Ou SH, Kim DW, Salgia R, Fidias P, Engelman JA, Gandhi L, Jänne PA, Costa DB, Shapiro GI, Lorusso P, Ruffner K, Stephenson P, Tang Y, Wilner K, Clark JW, Shaw AT: Activity and safety of crizotinib in patients with ALK-positive non-small-cell lung cancer: updated results from a phase 1 study. Lancet Oncol 2012, 13(10):1011-1019.

17. U.S. Department of Health and Human Services, Common Terminology Criteria for adverse Events (CTCAE) Version 4.0 [http://evs.nci.nih.gov/ftp1/ CTCAE/About.html]

18. Xalkori; Prescribing Information [http://www.accessdata.fda.gov/ drugsatfda_docs/label/2012/202570s003lbl.pdf]

19. Center for Drug Evaluation and Research, Application Number: 2025700rig1s000, CLINICAL PHARMACOLOGY AND BIOPHARMACEUTICS REVIEW(S). [http://www.accessdata.fda.gov/drugsatfda_docs/nda/2011/ 2025700rig1s000ClinPharmR.pdf]

\section{Submit your next manuscript to BioMed Central and take full advantage of:}

- Convenient online submission

- Thorough peer review

- No space constraints or color figure charges

- Immediate publication on acceptance

- Inclusion in PubMed, CAS, Scopus and Google Scholar

- Research which is freely available for redistribution

Submit your manuscript at www.biomedcentral.com/submit
C BioMed Central 